\title{
Assessment of the nutritional status of junior high school students - evidence from Mfantseman municipality of Ghana
}

\author{
Kwaw Emmanuel ${ }^{1}$, Sackey, Augustina Sackle ${ }^{1}$, Awere, Eric ${ }^{2}$ \\ ${ }^{1}$ Department of Hotel, Catering and Institutional Management, Cape Coast Polytechnic, Cape Coast, Ghana \\ ${ }^{2}$ Department of Civil Engineering, Cape Coast Polytechnic, Cape Coast, Ghana
}

\section{Email address:}

nyangoahkwaw@yahoo.co.uk (K. Emmanuel), sacklesackey@yahoo.com (S. A. Sackle), ericawere@gmail.com (A. Eric)

\section{To cite this article:}

Kwaw Emmanuel, Sackey, Augustina Sackle, Awere, Eric. Assessment of the Nutritional Status of Junior High School Students Evidence from Mfantseman Municipality of Ghana. Science Journal of Public Health. Vol. 1, No. 5, 2013, pp. 222-226.

doi: $10.11648 /$ j.sjph.20130105.16

\begin{abstract}
Malnutrition is one of the major problems facing the developing countries, especially among children. It is estimated that, $28 \%$ of children under the age of five are stunted whilst $14 \%$ are underweight in Ghana. Minister of Food and Agriculture in 2004 asserted that the Intelligent Quotient (IQ) of Ghanaian children has generally reduced due to poor dietary composition of their food coupled with little attention paid to good nutrition and that the nation is likely to suffer the consequences of unintelligent generation. It is against this background that this study was conducted to assess the nutritional status of Junior High School (JHS) students in the Mfantseman Municipality in the Central Region of Ghana with the objectives of estimating the body mass index (BMI) of the students through anthropometric measurements and use the BMI to determine their nutritional status as well as finding out factors contributing to their nutritional status. The study used purposive, convenient and random sampling techniques to select 7320 school children. Data was collected on the students' age, height and weight. The Body Mass Index (BMI) for age was calculated and compared with the 2007 WHO reference to identify their nutritional status. The study revealed that overall prevalence of malnutrition in the community was high with $25.9 \%$ of the children being overweight, 5.5 and $5.8 \%$ been lean or severely lean while $39.0 \%$ were normal. The incidence of malnutrition was prevalent among boys than girls. The high incidence of malnutrition may be attributed to improper dietary habits, unawareness of balanced diet, poor prenatal nutrition and low family income.
\end{abstract}

Keywords: Nutritional Status, Malnutrition, Body Mass Index, Dietary Habits, Mfantseman Municipality

\section{Introduction}

One of the major issues facing the world today is malnutrition among children. The consequences of malnutrition among school age children streams from severe under-nutrition such as underweight, stunted and wasted to over-nutrition. Poor nutrition and health among children have been identified to contribute to the general inefficiency of educational systems world-wide [1]. Malnutrition during school age period results in poor academic performance and physical development [2]. These findings have been supported by various literatures $[3 ; 4 ; 5 ; 6 ; 7 ; 8]$.

On the global front, it is estimated that 226 million children are stunted, almost 67 million are wasted and 183 million are underweight $[9,10]$. About $11 \%$ of the global disease burden and 53\% of child deaths in developing countries is also attributed to child malnutrition [11]. This problem is especially chronic in the developing countries and more prevalent in rural than in urban areas. This is reiterated by [11] that $80 \%$ of the world's undernourished children live in just 20 Countries in the developing world.

In Ghana, the 2008 Ghana Demographic and Health Survey (GDHS) shows that $28 \%$ of children under the age of five are stunted (too short for their age), 13.9\% are underweight whilst $9 \%$ are wasting (too lean for height) (Table 1). Otoo [11] has also reported that about 39\% of all Ghanaian 2 year olds are moderately or severely stunted. Moreover, although there is little statistics in the country to ascertain the IQ of children in Ghana, Major Courage Quashigah (rtd), former Minister for Food and Agriculture 
asserted that the Intelligent Quotient (IQ) of Ghanaian children has generally reduced due to poor dietary composition of their food coupled with little attention paid to good nutritious diet and that the nation is likely to suffer the consequences of unintelligent generations [12].

Table 1. Prevalence of Under-Five Malnutrition in Ghana

\begin{tabular}{llllll}
\hline $\begin{array}{l}\text { Type of } \\
\text { malnutrition }\end{array}$ & $\begin{array}{l}\text { National } \\
\text { Total } \\
(\%)\end{array}$ & $\begin{array}{l}\text { Urban } \\
(\%)\end{array}$ & $\begin{array}{l}\text { Rural } \\
(\%)\end{array}$ & $\begin{array}{l}\text { Central } \\
\text { Region } \\
(\%)\end{array}$ & Rank \\
\hline Stunted & 28 & 21 & 32 & 34 & $3^{\text {rd }}$ \\
Wasted & 9 & 8 & 9 & 12 & $3^{\text {rd }}$ \\
Underweight & 14 & 11 & 16 & 17 & $3^{\text {rd }}$ \\
Overweight & 5 & 7 & 4 & 10 & $2^{\text {nd }}$ \\
\hline
\end{tabular}

Source: [13]

The Central region in which Mfantseman Municipality is located is ranked $3^{\text {rd }}$ in the country in terms of the proportion of children who are underweight, stunted, wasted and $2^{\text {nd }}$ in Overweight as shown in Table 1.

Improving the nutritional status of people particularly school age children in all countries have been widely agreed at many international conferences and summits. A typical example is the MDG 1 Target $1 \mathrm{C}$ : Halving the proportion of people who suffer from extreme hunger by 2015. The level of malnutrition in a child can be influenced by the mother's education. For instance children born to mothers with at least some secondary education are substantially less likely to be stunted (18\% against 30\%), wasted (5\% against $12 \%$ ) or underweight (7\% against $17 \%$ ) [14]. In the Central Region underweight is prevalent in male children whiles it is prevalent in female children in the Northern Region, Accra and Kumasi. On the whole, male children (15 percent) are more likely to be underweight than female children (12 percent) [14].

In view of the prevalence of malnutrition in Ghana particularly Central Region and its consequences on the individual and the nation, this paper seeks to assess the nutritional status of Junior High School Students (JHS 1-3) in the Mfantseman Municipality, Central Region of Ghana. The objectives of the research are to estimate the body mass index (BMI) of the students through anthropometric measurements and use the BMI to determine their nutritional status as well as assessing factors that contribute to their nutritional status.

\section{Subjects, Materials and Methods}

A one-time cross-sectional study was carried out among selected Junior High School (JHS 1 - JHS3) students between the ages of $11-14$ years in Mfantseman Municipality, Ghana. The period of the study was 2011/2012 academic year. All the One hundred and fortyfour (144) Junior High schools (106 government-owned and 38 private-owned) with a student population of 12,342 were included in the study. Out of the total student population, 7320 students (4256 males and 3064 females) were selected for the study using convenience and simple random sampling methods. Only students present in school at the time of the study were selected for the study.

A pre-designed and pre-tested performa was developed for the study. Anthropometric measurements (age, weight and height) were recorded for each subject. The accurate age of the subjects was recorded from the schools' admission books and confirmed from the Child Health Records card (commonly known as the 'weighing card'). Weight and height of the subjects were measured in-situ at the time of visit. A bathroom scale which was regularly calibrated against known weights was used to measure the weights of the subjects. The zero error of the weight was daily checked for and removed if present. Weight was taken with minimum clothing (only school uniform) since adequate privacy was not available. Their weight was recorded to the nearest gram.

Height was measured by affixing a metric tape to a wall perpendicular with the floor and sliding a right angle down to the child's crown. All the subjects stood against the wall without foot wear and with heels together and their heads positioned so that the line of vision was perpendicular to the body. Height was recorded to the nearest $\mathrm{cm}$. To assure consistency in the method of measurement of anthropometric data, all surveyors were supervised by the authors. The criterion set for assessing nutrition status in this study was Body Mass Index (BMI) for age in relation to the 2007 WHO growth charts with labels. The BMI for age was calculated from the formulae below.

$$
\operatorname{BMI}\left(\mathrm{kg} / \mathrm{m}^{2}\right)=\frac{\text { Weight }(\mathrm{kg})}{\operatorname{Height}(\mathrm{m}) \times \operatorname{Height}(\mathrm{m})}
$$

Status of parents/guardians

Subjects were asked for their parents or guardians education background and occupation. Responses were recorded and presented in figures.

Ethical Consideration

Permission was obtained from the Mfantseman Municipality Education and heads of the respective schools before conducting the study.

\section{Results and Discussion}

\subsection{Results}

Table 2. Distribution of school children according to age

\begin{tabular}{|c|c|c|c|c|c|c|}
\hline $\begin{array}{l}\text { Age } \\
\text { grou } \\
\text { p/Yrs }\end{array}$ & $\begin{array}{l}\text { Boys } \\
\text { No. of } \\
\text { Childr } \\
\text { en }\end{array}$ & $\begin{array}{l}\text { Percen } \\
\text { tage } \\
(\%)\end{array}$ & $\begin{array}{l}\text { Girls } \\
\text { No. of } \\
\text { Child } \\
\text { ren } \\
\end{array}$ & $\begin{array}{l}\text { Percen } \\
\text { tage } \\
(\%) \\
\end{array}$ & $\begin{array}{l}\text { Total } \\
\text { No. of } \\
\text { Child } \\
\text { ren } \\
\end{array}$ & $\begin{array}{l}\text { Percenta } \\
\text { ge }(\%)\end{array}$ \\
\hline 11 & 1051 & 24.69 & 791 & 25.82 & 1842 & 25.16 \\
\hline 12 & 1057 & 24.84 & 730 & 23.83 & 1787 & 24.41 \\
\hline 13 & 1099 & 25.82 & 786 & 25.65 & 1885 & 25.75 \\
\hline 14 & 1049 & 24.65 & 757 & 24.71 & 1806 & 24.67 \\
\hline Total & 4256 & 100.00 & 3064 & 100.00 & 7320 & 100.00 \\
\hline
\end{tabular}

The age group distribution of the students is shown in 
Table 2. Out of the 7320 school children aged between 11 and 14years used for the study, 4256(58.14\%) were boys while 3064(41.86\%) were girls.

Table 3. Anthropometric measurement of the school children

\begin{tabular}{|c|c|c|c|c|}
\hline $\begin{array}{l}\text { Age } \\
\text { groups } \\
\text { (Yrs) } \\
\end{array}$ & $\begin{array}{l}\text { No. of } \\
\text { Childre } \\
\text { n }\end{array}$ & $\begin{array}{l}\text { Weight/Kg } \\
(\text { Mean } \pm \text { SD) }\end{array}$ & $\begin{array}{l}\text { Height/M } \\
(\text { Mean } \pm \text { SD } \\
\text { ) }\end{array}$ & $\begin{array}{l}\text { BMI }\left(\mathrm{Kg} / \mathrm{M}^{2}\right) \\
(\mathrm{Mean} \pm \mathrm{SD})\end{array}$ \\
\hline Eleven & 1842 & $\begin{array}{l}47.46 \pm 10.3 \\
2\end{array}$ & $1.51 \pm 0.09$ & $20.81 \pm 4.97$ \\
\hline Twelve & 1787 & $\begin{array}{l}47.56 \pm 10.1 \\
0\end{array}$ & $1.51 \pm 0.09$ & $20.86 \pm 4.93$ \\
\hline Thirteen & 1885 & $\begin{array}{l}48.39 \pm 10.4 \\
0\end{array}$ & $1.52 \pm 0.09$ & $20.94 \pm 5.04$ \\
\hline Fourteen & 1806 & $\begin{array}{l}47.69 \pm 10.6 \\
4\end{array}$ & $1.52 \pm 0.09$ & $20.64 \pm 5.06$ \\
\hline
\end{tabular}

The average anthropometric measurement of the school children in terms of weight and height did not differ greatly (Table 3.0) among the various age groups but on the average those age 13years were heavier $(48.39 \pm 10.40 \mathrm{Kg})$ compared to the other age groups.

The education background of the children's parents/guardians as shown in Figure 1.0 depicts that majority $(73.89 \%)$ have had some formal education with $26.11 \%$ been illiterates. It is noteworthy that despite their formal education most parents/guardians educational background were low with few having had tertiary $(3.43 \%)$ and Diploma/Vocation (13.74\%) education.

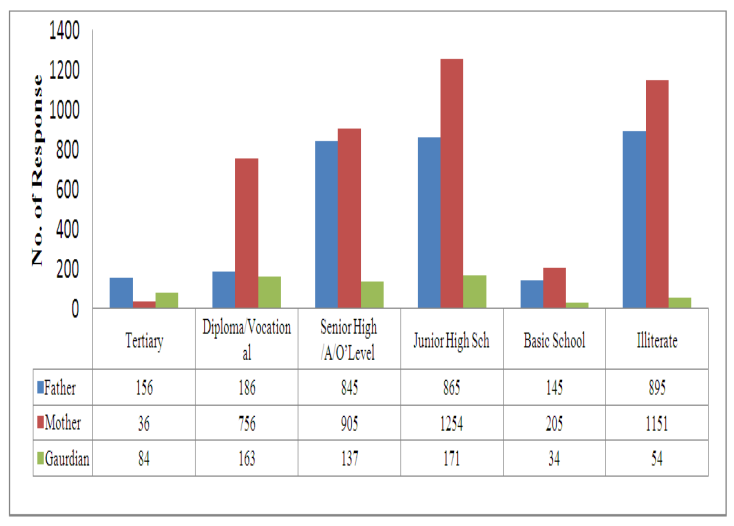

Figure 1. Education background of student's parents/Guardians

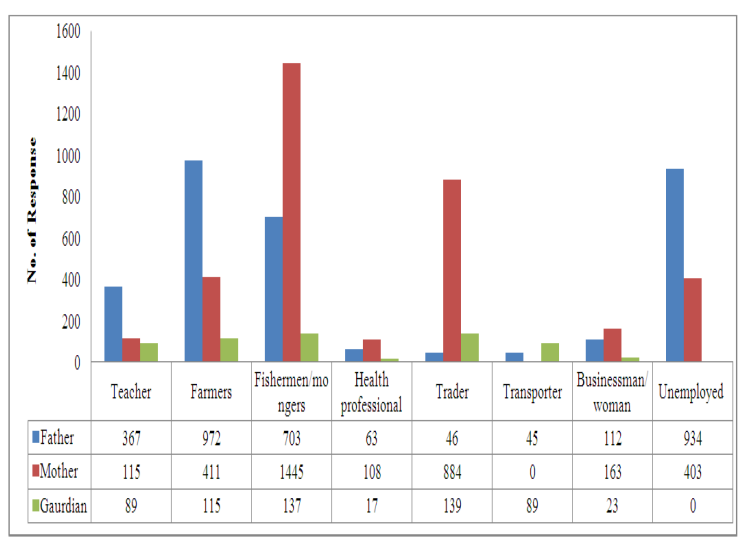

Figure 2. Occupation of student's parents/Guardians
Majority of the parents of the children were Fishmongers (1445) and traders (1445) while $18.1 \%$ of them unemployed (Figure 2). The dominancy of fishermen, fishmongers and traders as occupations of the parents and guardians of the children is because the municipal has most towns along the Gulf of Guinea. Others were into teaching (7.74\%) farming $(20.30 \%)$, health sector $2.55 \%$ while $4.04 \%$ and $1.82 \%$ were businessmen/women and transporters respectively. The absence of women in the transport sector is that in Ghana jobs like driving are for men with just few ladies engaging in that business.

Table 4. Distribution of the nutritional status of the school children

\begin{tabular}{lllllll}
\hline $\begin{array}{l}\text { Nutritio } \\
\text { nal } \\
\text { status }\end{array}$ & $\begin{array}{l}\text { Boys } \\
\text { No. of } \\
\text { childr } \\
\text { en }\end{array}$ & $\begin{array}{l}\text { \% } \\
\text { Freq. }\end{array}$ & $\begin{array}{l}\text { Girls } \\
\text { No. of } \\
\text { childr } \\
\text { en }\end{array}$ & $\begin{array}{l}\text { \% } \\
\text { Freq. }\end{array}$ & $\begin{array}{l}\text { No. of } \\
\text { children }\end{array}$ & $\begin{array}{l}\text { \%o } \\
\text { Freq. }\end{array}$ \\
\hline $\begin{array}{l}\text { Severe } \\
\text { Leanness }\end{array}$ & 341 & 8.0 & 82 & 2.7 & 423 & 5.8 \\
Leanness & 264 & 6.2 & 135 & 4.4 & 399 & 5.5 \\
Normal & 1679 & 39.5 & 1177 & 38.4 & 2856 & 39.0 \\
Overwei & 1035 & 24.3 & 859 & 28.0 & 1894 & 25.9 \\
ght & 937 & 22.0 & 811 & 26.5 & 1748 & 23.9 \\
Obesity & 937 & 100.0 & 3064 & 100.0 & 7320 & 100. \\
Total & 4256 & 100.0 & \\
\hline
\end{tabular}

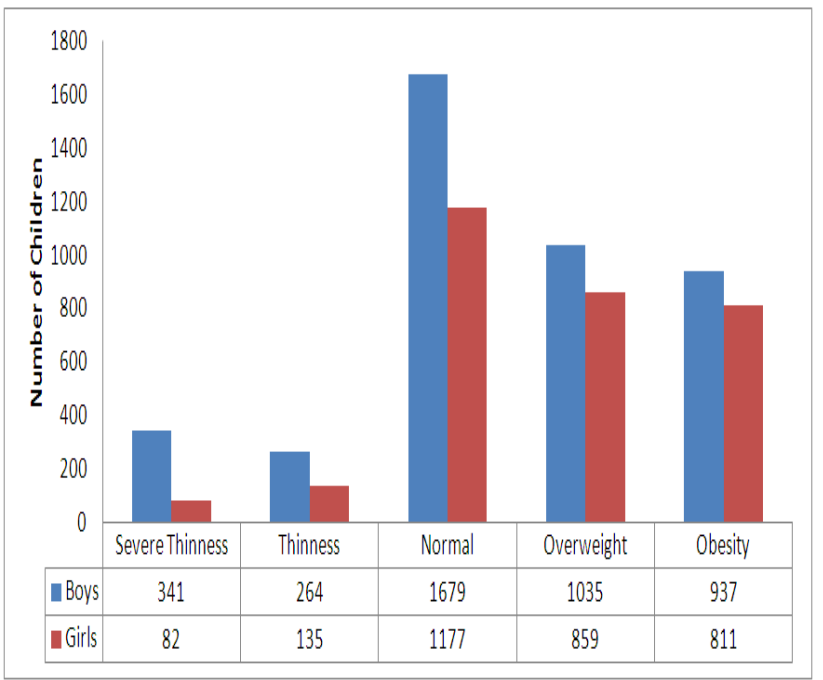

Figure 3. Nutritional status of the school children

The nutritional status of the school children as shown in Figure 3.0 depicts that $1679(39.5 \%)$ and $1177(38.4 \%)$ of the boys and girls respectively were normal while 1035 $(24.3 \%)$ and $859(28.0 \%)$ were overweight. The results also showed that $937(22.0 \%)$ and $811(26.5 \%)$ boys and girls respectively were obesed while 605 (14.2\%) and 217 (7.1\%) boys and girls respectively were lean and severely lean.

\subsection{Discussion}

Many research studies indicated that malnutrition including underweight and stunting constituted major health problems among school children. In the present study majority of the children (1679 (39.5\%) boys and 
$1177(38.4 \%)$ girls) as shown in Figure 3.0 were normal while $1035(24.3 \%)$ and $859(28.0 \%)$ were overweight. The results also showed that $937(22.0 \%)$ and $811(26.5 \%)$ boys and girls respectively were obsessed while $605(14.2 \%)$ and $217(7.1 \%)$ boys and girls respectively were either lean of severely lean. This pattern of nutritional status has been reported in a study by [15] of which majority of the children $(65.75 \%)$ belonged to normal nutritional status and 25 to 35 percent exhibited short and long duration malnutrition in all age groups.

PohSiang [16] conducted a study on nutritional status of 104 Indian children in the rubber plantation sector of Malaysia. The result showed that about 42 per cent of male and 37 per cent of female children were under weight, while 39 per cent males and 27 per cent of females were stunted. [17] reported $54 \%$ as lean in the rural area of Wardha and in Bangladesh and [18] found the prevalence of leanness to be $67 \%$. All these studies show a higher degree of under nutrition than the present study. In the present study under nutrition was significantly more prevalent in boys than girls even though the level of under nutrition recorded was quite low. However [19] reported the prevalence of higher under nutrition in boys $(53 \%)$ than girls $(40 \%)$. On the contrary [17] found that leanness was significantly more prevalent in girls than boys. Another report by [8] also revealed a higher incidence of malnutrition among boys (53.85\%) than among girls $(49.25 \%)$ and commended that, the high incidence of malnutrition among boys may be attributed to improper dietary habits and unawareness of balanced diet, high frequency of early age group pediatric diseases in boys than girls.

Even though the study did not compare their nutritional status to their academic performance, studies [5;6] have revealed that malnourished children with poor physical growth perform poorly in intelligence test and emphasized that malnutrition during childhood can lead to irreversible impairment of mental function in later life.

\section{Conclusion}

The overall prevalence of malnutrition in the Municipality was high with $25.9 \%$ of the children being overweight, $5.5 \%$ and $5.8 \%$ been lean or severely lean. The incidence of malnutrition was prevalent among boys than girls. Although the Government of Ghana is still in the process of restoring the economy, it does have national intervention programs such as the school feeding program, vitamin A supplement program and nutritional education aimed at improving nutritional status of children of schoolgoing age. However the study did not confirm the impact of these interventions on the nutritional status of the school children. The high incidence of malnutrition may be attributed to improper dietary habits, unawareness of balanced diet, high frequency of early age group paediatric diseases, poor prenatal nutrition, food insecurity and low family income.

\section{References}

[1] Afoakwa, E. O. (2007). School Feeding Programmes in Africa - Current Developments and Challlenges. WISHH Workshop Ghana 2007, Accra, Ghana

[2] Sunita, K. 2005, Assessment of nutritional status of school children from rural Bihar. The Indian Journal of Nutrition and Dietetics, 42: 326.

[3] Karim, R., Bhuyan, M. A. H. and Shukanta, S. 1991, Effect of nutrition on school performance in a primary school in Dhaka, Bangladesh. Indian Journal of Nutrition and Dietetics, 28: 171-176.

[4] Pollitt, E., Cueto, S. and Jacoby, E. R. (1998). Fasting and cognition in well and undernourished school children: a review of three experimental studies. American Journal of Clinical Nutrition, 67: 797-840.

[5] Fernstrom, J. D., Uauy, R. and Arroya, P. (2001). Nutrition and brain. Nestle Nutri. Work. Series, 5: 69-72.

[6] Upadhyaya, S. K., Singh, T. B., Alka Srivastava and Bhatia, B. D., 2001, Perceptual development in relation to nutritional status. Indian Journal of Pediatrics, 68 (4): $327-$ 332.

[7] Sorhaindo, A. and Feinstein, L. (2006). What is the relationship between child nutrition and school outcomes? Wider Benefits of Learning Research Report No.18, London.

[8] Hasan, I., Zulkifle, M. and Ansari, A. H. (2011). An assessment of nutritional status of the children of government Urdu higher primary schools of Azad Nagar and its surrounding areas of Bangalore. Archives of Applied Science Research, 3 (3), 167-176

[9] Nemapare, P. N. (1999). Health and nutrition status of rural children. Earthwatch Institute Watertown: U.S.A.

[10] Anonymous, (2005). The state of world's children. UNICEF report, Oxford University Press, New Delhi, pp. 112-118.

[11] Otoo, G. E. (2008). Nutritional Status of Children in Ghana. WISHH Ghana Annual Conference, 6th November, 2008, Accra-Ghana.

[12] Ghana News Agency (2004). Poor Nutrition affects IQ of Ghanaian Children. Retrieved on June 16, 2013.

[13] Ghana Statistical Service (GSS), Ghana Health Service (GHS), and ICF Macro. 2009b. Ghana Demographic and Health Survey 2008: Key Findings. Calverton, Maryland, USA: GSS, GHS, and ICF Macro.

[14] Ghana Statistical Service (GSS), Ghana Health Service (GHS), and ICF Macro. 2009a. Ghana Demographic and Health Survey 2008: Preliminary Report. Calverton, Maryland, USA: GSS, GHS, and ICF Macro.

[15] Suvarna, (2007). Nutritional Status, Level of Intelligence and Participation in Extracurricular Activities of School Children. Master's Thesis. University of Agricultural Sciences, Dharwad.

[16] PohSiang C. (1990). Nutritional status of Indian pre-school children in the rubber plantation sector in Malaysia. The Indian J. nutr. Dietet., 27: 144. 
[17] Deshmukh, P. R., Gupta, S. S., Bharmbe, M. S., Dongre, A R., Maliye, C., (2006). Nutritional status of adolescents in rural Wardha. Indian Journal of Paediatrics 73, 139-141.

[18] Shahabuddin, A. K., Talukdar, K., Talukdar, M. K., Hassan, M., Seal, A., (2000). Adolescent nutrition in a rural community in Bangladesh. Indian Journal of Paediatrics 67, 93-98.
[19] Venkaiah, K., Damayanti, K., Nayak, M. U. and Vijayraghavan, K. (2002). Diet nutritional status of rural adolescents in India. European Journal of Clinical Nutrition 56 (11), 19-25 